\title{
FRIEDRICH NIETZSCHE (1844-1900)
}

\section{A BRIEF LIFE IN A PRELUDE AND FIVE DECADES}

Prelude: Early childhood (1844-1849)

Firstborn of a Lutheran minister and his wife, living in a small provincial town in what is now eastern Germany.

The precocious youth (1849-1858)

Bright, serious boy of many talents (musical as well as scholastic), left fatherless at five, raised in an adoring all-female household.

The brilliant student (1858-1869)

Classics student excelling in his studies, first at an elite boarding school and then at the universities at Bonn and Leipzig; aspiring composer and fine pianist; discovers Schopenhauer and meets Wagner.

The rebellious professor (1869-1879)

Prodigy in classical philology, a professor at Basel at twenty-four; unconventional interests and writings antagonize his colleagues; an avid Wagnerian (still composing himself); cultural critic becoming a philosopher, while struggling with academic life and debilitating illnesses.

The nomad philosopher (1879-1888)

Pensioned retiree at thirty-four; plagued with recurring severe health problems; alienated from academic life and nearly everything else; living alone in Swiss and Italian boardinghouses - and proceeding from "freespirited" reflections to Zarathustra, and on toward a "philosophy of the future" and a "revaluation of all values."

The insane invalid (1889-1900)

Mere shell following a complete physical and mental collapse (probably of syphilitic origin) in early 1889 -at the age of only forty-four; a decade of empty madness before the final curtain. 


\section{CHRONOLOGY}

1844 Friedrich Wilhelm Nietzsche is born on October 15 in Röcken, in the Prussian province of Saxony.

1849 Father dies (at the age of thirty-six).

1858-1864 Attends the classics-oriented boarding school Schulpforta. (Plays the piano and composes on the side.)

1864 Enters Bonn University to study classical languages and literatures.

1869 Associate professor of classical philology (before even completing his Ph.D.) at the Swiss university at Basel.

1870 Full professor at Basel. Enlists as a medical orderly in the Franco-Prussian War, contracting serious illnesses.

1872 First book The Birth of Tragedy appears (and is met with scholarly derision) - his only major classical studies publication.

1873-1874 Publishes the first three Untimely Meditations, including the essays On the Uses and Disadvantages of History for Life and Schopenhauer as Educator.

1876 Writes a fourth Meditation in homage to Wagner, but his enthusiasm for Wagner cools.

1878 The first volume of Human, All Too Human (638 aphorisms) appears. Wagner sends him Parsifal, and their estrangement deepens.

1879 Resigns (with pension) from his position at Basel, incapacitated by his health problems. Begins spending his summers in the Swiss Engadine region, and his winters in northern Italy, living in boardinghouses.

1879-1880 Writes two sequels to Human, All Too Human, subsequently published as the two parts of its second volume (another 758 aphorisms).

1881 Publishes Daybreak (575 more aphorisms). Alternative periods of depression and exhilaration. First summer in Sils Maria, where the idea of "eternal recurrence" comes to him. 
1882 The year of his intense but short-lived relationship with Lou Salome, which ends badly. Publishes the initial fourpart version of The Gay Science (342 aphorisms and reflections).

1883 The first two parts of Thus Spoke Zarathustra are written and published. Wagner dies. Estrangement from family and friends; depression. Resolves against living in Germany.

1884 Completes and publishes the third part of Zarathustra. Breaks with his sister, unable to endure her anti-Semitic, pro-"Teutonic" fiancée Bernard Förster. (She marries him the next year, to Nietzsche's disgust and distress, accompanying him to Paraguay where he sought to found a Teutonic colony.)

1885 The fourth part of Zarathustra is written, but is only privately printed and circulated. Condition worsens.

1886 Beyond Good and Evil (296 aphorisms and reflections in nine parts, plus a poem "Aftersong") is published. New editions of most pre-Zarathustra works are prepared and supplied with prefaces.

1886-1887 An expanded second edition of The Gay Science is prepared and published, with a new preface and fifth part consisting of 41 additional reflections, and an appendix of poetry, "Songs of Prince Vogelfrei."

1887 On the Genealogy of Morals appears, consisting of a preface and three "essays" (of 17, 25 and 28 numbered sections, respectively). Completes orchestral score for Hymnus an das Leben. Begins working on magnus opus, to be called The Will to Power.

1888 The Case of Wagner is published; and Twilight of the Idols, The Antichrist, Nietzsche contra Wagner, Dionysian Dithyrambs (a collection of poems), and Ecce Homo are all written. The Will to Power project is dropped, in favor of a projected four-part Revaluation of All Values. Condition deteriorates.

1889 Collapses in early January in Turin, at the age of 44 . (Nietzsche never recovers, living his final eleven years in invalid insanity in the care of his mother and sister.) Twilight of the Idols is published in the same month. 
1892 First public edition of the fourth part of Zarathustra appears.

1893 Sister returns from Paraguay, and-under the name Elizabeth Förster-Nietzsche-assists their mother in the management of her brother's affairs.

1895 The Antichrist and Nietzsche contra Wagner are published.

1897 Mother dies, leaving complete control of Nietzsche's care-and of his literary estate-to his sister, who exploits his growing fame and fosters the assimilation of his thought to right-extremist political purposes during the next four decades.

1900 Nietzsche dies, on August 25, in Weimar.

1901 Sister publishes an arrangement of selections from his notebooks of 1883-1888 under the title The Will to Power, and in his name.

1908 Ecce Homo is finally published (twenty years after it was written).

1910-1911 First edition of Nietzsche's collected works is published under the supervision of his sister-including a greatly expanded edition of The Will to Power.

1935 Sister dies, triumphant in the knowledge that her brother had come to be regarded by Hitler and Mussolini (and many others) as the philosopher of National Socialism and Fascism-a travesty that would plague Nietzsche's reception for the next half-century.

1967-1984 Publication of the Kritische Gesamtausgabe of Nietzsche's works, Nachlass, and letters. 